\title{
The Economic Implications of a Complete Free Trade and an Alternative Form of Free Trade in Sugar Through 1980
}

\author{
by \\ M. RaQuibuzzaman*
}

\section{INTRODUCTION}

In recent years, it has been emphasized by many economists that the less developed countries cannot achieve self-sustaining economic growth unless they are given fair opportunities to sell their exportables in the world market. It is argued that the less developed countries are losing potential investment resources as a result of trade restrictions imposed by the developed countries on primary commodities. Sugar provides an example of a commodity whose free entry into world trade has been restricted by the United States and most of the developed countries of Europe. Sugar is the principle earner of foreign exchange for many developing countries. A decrease in the quantity of exports or a fall in the price has an important impact on the overall development of their economies. In recent years, the world production of centrifugal sugar has ranged between 64 and 66 million metric tons of raw sugar. Of this total production, Europe's share ranged from 23 to 24 million tons, or approximately 36 per cent. The United States, including Hawaii, produced approximately 5 million tons. Thus, nearly 50 per cent of world sugar production comes from the developed countries.

It is frequently argued that the developed countries of Europe and America have no comparative advantage in the production of sugar and, therefore, they should not encourage the production of either beet or cane sugar through artificial price supports and protectionist policies. A removal of re-

*The author is a Research Economist at the Institute. He is deeply indebted to Professors D. G. Sisler, John W. Mellor and Tom E. Davis, all of Cornell University, for their valuable comments and suggestions on the author's unpublished doctoral dissertation [13] from which this paper is prepared. The author is thankful to Dr. Azizur Rahman Khan and Dr. S. R. Bose, both of the Institute, for their suggestions and comments. He is, however, responsible for any remaining errors or omissions.

The author submitted his thesis to the Faculty of the Graduate School of Cornell University, U.S.A. in January 1970 . This paper draws on Chapters I, II, III and VI of the dissertation. The section on Pakistan is, however, a later addition to the original study. 
strictive measures by these countries would help the developing countries to reap the benefit of their comparative advantage. Increased exports would help them earn the much-needed foreign exchange for the growth of their economies. The present policies pursued by the developed countries, such as the United States and the United Kingdom, make the domestic production of sugar beet and sugarcane profitable to growers. Unless the farmers are otherwise compensated, a removal of the quota and/or tariff system would reduce their total income and probably cause them to cease production.

\section{Objectives and Methodology}

The main objective of this study is to analyze the implications of a complete free trade and an alternative form of trade in sugar on the economies of the developing as well as developed countries. This will be done on the basis of an analysis of comparative advantage in sugar production in the major sugar-exporting and importing countries.

Any analysis of the implications of altered world sugar policies is directly dependent upon accurate estimates of the costs of growing sugar in the leading sugar-producing nations. To the extent that such cost estimates are inaccurate or unavailable, conclusions concerning the results of removal of barriers to international trade in sugar will be erroneous. When starting this study, the author was aware that country-by-country cost data were difficult to obtain. However, the importance of the problem suggests that there is a merit in attempting the analysis because of the methodology and insights that may be provided. The analysis will hopefully indicate the directions of change and their relative importance resulting from different policies among developed and underdeveloped countries, even though specific qualification of results of altered policies is recognised to be directly dependent upon estimates of costs of production which may be erroneous.

This paper also aims at a brief analysis of Pakistan's foodgrain policies, particularly the policies with respect to sugar, in order to examine how far Pakistan's policies are guided by the principles of comparative advantage.

\section{IMPLICATIONS OF FREE TRADE AND ITS ALTERNATIVE FORM}

The world sugar market is peculiarly structured. About 65 per cent of the 18 million metric tons of raw sugar annually entering the world market is handled under preferential systems of special pricing arrangements (at average price of 133 dollars per metric ton (see [13, Chapter VI ])) which have no connection with the world spot market or futures trading on the London or United States sugar exchanges. The best known of these are the United States Sugar Act and the British Commonwealth Agreement. These pricing agreements are usually at prices above those quoted in London and New York. Mr. Evan Fisher, in an article published in Sugar Y Azucar [5, Pp. 29-30], writes that when 
"we speak of the 'world market' we are actually referring to about 10 per cent of the total production" or about 35 per cent of world trade in sugar (6 to 7 million metric tons annually).

The "world price" is actually a residual or marginal price at which only 10 per cent of the world's sugar production is sold. This "world price" is often below the cost of production; the loss to growers due to the low price is reimbursed in whole or in part by the governments of the exporting countries. The growers in these countries are paid a higher price for their product than the world market price. "The depressed world sugar prices have little short-term effect on production, because approximately 90 per cent of the world's sugar is not traded at the world market price" [5, p. 30]. During the 1960-66 period, the yearly average price of raw sugar was 76.06 dollars per metric ton.

It is often argued that free trade in sugar will immensely benefit the developing countries exporting sugar. These benefits would arise in two ways: first, free trade in sugar would be beneficial because prices would be expected to rise; second, the quantity of exports would be expected to expand markedly. It is believed that their exports will increase because they have comparative advantage in sugar production over some of the major developed sugar-producing countries whose production will decline under free trade. In order to examine these general observations or hypotheses, one has to have access to the information regarding which countries have comparative advantage in sugar production over others. A country is said to have a comparative advantage over another in the production of sugar if its opportunity cost of producing sugar is less than the other [11, Chapter 5]. Hardly any data on opportunity costs of producing sugar are available. For a commodity like sugar, international cost comparisons can best be made in terms of cost of producing raw sugar for which fairly reliable data are available for some major sugar-producing countries, although such cost data are not available for all the 103 or so countries that produce sugar in large or small quantities. Most of the data concerning internationally traded sugar are recorded in terms of raw sugar. A comparison of cost of producing beet and cane sugar will be less accurate not only because data are scarce and, in some cases, unreliable, but also because the sucrose contents of cane and beet vary from region to region and from country to country. The use of raw sugar eliminates this problem but not the problem of accuracy. This is because hardly any country published the data on cost of producing raw sugar as such; but it is possible to estimate these data indirectly by following certain standard procedures.

The data on cost of producing raw sugar used here are taken mainly from the study of R. H. Snape [14; see also 10]. Dr. Snape gives some idea about the 
costs of producing raw sugar in some selected countries1. It is assumed here that the 1959 data on cost of production of raw sugar estimated by Snape (Table I) are reasonable approximations of the true costs and that these costs hold true for the 1960-67 period. In Table I the costs of production of raw sugar for 34 selected countries are presented along with their average annual production and consumption during 1964-66. Data on costs of production for countries in subgroup 1 are taken from Snape's study. Cost figures in subgroup 2 are estimated indirectly. The European weighted average cost of production of sugar was assumed to represent the costs of production in Poland, Czechoslovakia, the United Socialist Soviet Republic (USSR), Spain and Turkey. The average cost in 39 other countries, shown as "Other States" in Table I, is assumed to be the weighted average cost of all other countries producing annually about one hundred thousand metric tons or more of sugar and not listed in Table I2. The average annual world production and consumption during 1964-66 was about 61.53 and about 58.99 million metric tons, respectively.

It is assumed in this study that the costs of production presented in Table I will remain constant through 1980 . It may be argued that labour cost, machinery cost, land cost, etc., will continue to rise and, hence, one should project this increase in estimated cost forward. 'The problem is that even if one is able to project the annual rise of the United States or the United Kingdom production costs through 1980 on the basis of historical increases in the cost of various agricultural inputs, there is no way of doing this for the other countries of the world. One is forced, therefore, to assume as a first approximation that the costs of production in the United States or the United Kingdom and in other countries will rise at the same rate over the next 13 years and, hence, relative costs in all these countries would remain unchanged. Perhaps it is also rational to assume that at least the relative magnitude of gains or losses from free trade can be accurately determined by using 1959 production costs throughout the period. It is possible to demonstrate, following the estimation procedure of Snape, that the costs of production of raw sugar in the selected countries would not have been much different in 1967 from those of 1959, presented in Table I, because of the persistence of low world price of sugar and relatively stable domestic prices of sugar in the selected countries ${ }^{3}$. It is calculated that 72.31 million metric tons of sugar are required to meet world demand in 1973 and 87.22 million metric tons in 1980. The demand for sugar in individual countries can be estimated given the available data on world demand [13, Table 22]. The supplies

1Snape's study includes the cost-of-production data for all the major exporting countries, except the countries in Eastern Europe. Among the major importers, cost data are available for the United States, the United Kingdom and West Germany. His study does not provide cost data for the Communist countries. For the estimation procedure used by Snape in deriving cost data, see Appendix A.

2For details, see Appendix B.

3See Appendix A for the estimation procedure of R. H. Snape. 
TABLE I

COSTS OF PRODUCTION, PRODUCTION AND CONSUMPTION OF SUGAR IN SELECTED COUNTRIES

\begin{tabular}{|c|c|c|c|}
\hline Country & $\begin{array}{l}\text { Estimated cost } \\
\text { of production }\end{array}$ & $\begin{array}{l}\text { Annual production } \\
\text { of raw sugar } \\
\text { (average of 1964-66) }\end{array}$ & $\begin{array}{l}\text { Annual consumption } \\
\text { of raw sugar } \\
\text { (average of 1964-66) }\end{array}$ \\
\hline Subgroup 1 & $\begin{array}{l}\text { (US dollars per } \\
\text { metric ton) }\end{array}$ & $\left(\ldots . . .000^{\prime} n\right.$ & ic tons......) \\
\hline $\begin{array}{l}\text { Dominican Republic } \\
\text { Peru } \\
\text { Taiwan } \\
\text { South Africa } \\
\text { Cuba } \\
\text { Mauritius } \\
\text { Argentina } \\
\text { Australia } \\
\text { Guayana } \\
\text { Jamaica } \\
\text { Brazil } \\
\text { Barbados } \\
\text { Trinidad-Tobago } \\
\text { Fiji } \\
\text { Netherlands } \\
\text { British Honduras } \\
\text { Mexico } \\
\text { Philippines } \\
\text { Belgium-Luxembourg } \\
\text { Indonesia } \\
\text { France (Metropolitan) } \\
\text { United Kingdom } \\
\text { India } \\
\text { Italy } \\
\text { Hawaii (US) } \\
\text { Puerto Rico (US) } \\
\text { US (Mainland) } \\
\text { Germany (West) }\end{array}$ & $\begin{array}{r}60.63 \\
71.65 \\
71.65 \\
82.67 \\
88.18 \\
99.21 \\
99.21 \\
99.21 \\
99.21 \\
99.21 \\
104.72 \\
110.23 \\
110.23 \\
110.23 \\
110.23 \\
115.74 \\
115.74 \\
121.25 \\
121.25 \\
132.28 \\
132.28 \\
132.28 \\
137.79 \\
154.32 \\
154.32 \\
154.32 \\
165.35 \\
170.86\end{array}$ & $\begin{array}{r}700 \\
784 \\
964 \\
1,336 \\
5,180 \\
582 \\
1,112 \\
2,174 \\
290 \\
496 \\
3,949 \\
179 \\
233 \\
331 \\
619 \\
38 \\
2,097 \\
1,611 \\
468 \\
707 \\
2,188 \\
933 \\
3,322 \\
1,225 \\
1,098 \\
835 \\
3,812 \\
1,875\end{array}$ & $\begin{array}{r}110 \\
336 \\
141 \\
825 \\
478 \\
28 \\
894 \\
656 \\
24 \\
76 \\
2,779 \\
12 \\
43 \\
20 \\
730 \\
3 \\
1,485 \\
520 \\
360 \\
596 \\
1,710 \\
2,879 \\
2,811 \\
1,419 \\
39 \\
110 \\
9,160 \\
2,074\end{array}$ \\
\hline Subtotal: & & 39,138 & 30,318 \\
\hline
\end{tabular}

Subgroup 2

$\begin{array}{ll}\text { USSR } & 143.30 \\ \text { Poland } & 143.30 \\ \text { Czechoslovakia } & 143.30 \\ \text { China (Mainland) } & 123.46 \\ \text { Spain } & 143.30 \\ \text { Turkey } & 143.30 \\ \text { "Other States" } & 121.25\end{array}$

Subtotal :

Total:
143.30

123.46

143.30

21.25

\begin{tabular}{rr}
8,787 & 9,725 \\
1,667 & 1,141 \\
855 & 611 \\
2,200 & 2,330 \\
561 & 730 \\
671 & 517 \\
7,651 & 13,618 \\
\hline 22,392 & 28,672 \\
\hline 61,530 & 58,990
\end{tabular}

Source: $i$ ): Cost-of-production data from [14]. Also quoted in [10, Appendix $D$, Table 1], and Appendix B of this paper.

ii): Production data from $[8 ; 9]$. 
of sugar in individual countries in the future can also be roughly estimated, assuming constant costs, in the relevant range of production for every country. Under free trade, production will expand in low-cost countries and contract in high-cost countries till supply equals demand in the world as a whole. The following steps simplify the analysis:

First, the list of the countries in Table I is rearranged in Table II in a graduated scale of costs. The mainland US and West Germany have the highest costs. Puerto Rico (US) has the next highest cost and is the marginal country on this list. By progressively summing up the estimated production of countries listed in Table II, it can be determined that the production of Puerto Rico plus that of all countries with production costs lower than Puerto Rico could produce a quantity of sugar equivalent to world consumption stated above. The cost of producing sugar in Puerto Rico is 154.32 dollars per metric ton. Hence, it can be assumed that this price would bring forth production equal to consumption if world trade in sugar were unobstructed and price settled at a competitively
determined level.

Second, in order to show the implications of free trade over the projected period of 1967-80, two years, representing the midpoint and the end of the projections, have been selected. They are 1973 and 1980 . Estimates for all the years inbetween are not made to avoid enormous computational problems. It is felt that a year-by-year analysis will not be necessary to point out to the reader the importance of free trade in sugar to the developing as well as developed
countries.

Third, on the basis of the analysis of the economies of some of the sugarexporting and importing countries and on the basis of the information available from the Food and Agriculture Organisation's projections, demand for and production of sugar by the selected countries are estimated for 1973 and $1980^{4}$.

The world demand for sugar in the base period 1964-66 was 58.99 million metric tons. Projected demand in 1973 is 72.31 million metric tons. The percentage increase in demand in 1973 over the level of demand in 1964-66 is 23 . Taking into consideration the population growth rates, growth rates in income, present per capita consumption of sugar and the FAO projections of regional 4The analysis in Chapter II of the thesis [13] was entirely devoted to the sugar economies
of the selected countries. There, for each country, the trends in production, imports or exports climatic and soil conditions, availabilities of lantialities of increasing sugar production (based on long-term economic programmes) over time were elaborately discur production and the national of the major sugar-exporting countries could increase their discussed. It was found that some better seeds and fertilizer, while some other increase their production many-fold just by using appreciably because of limitations of resources countries are incapable of increasing sugar output growth rates in production, shown in this section, are based sar production. The estimated and on the FAO Projections [7, Pp. 181-194] mentioned earlier the analysis referred to above 


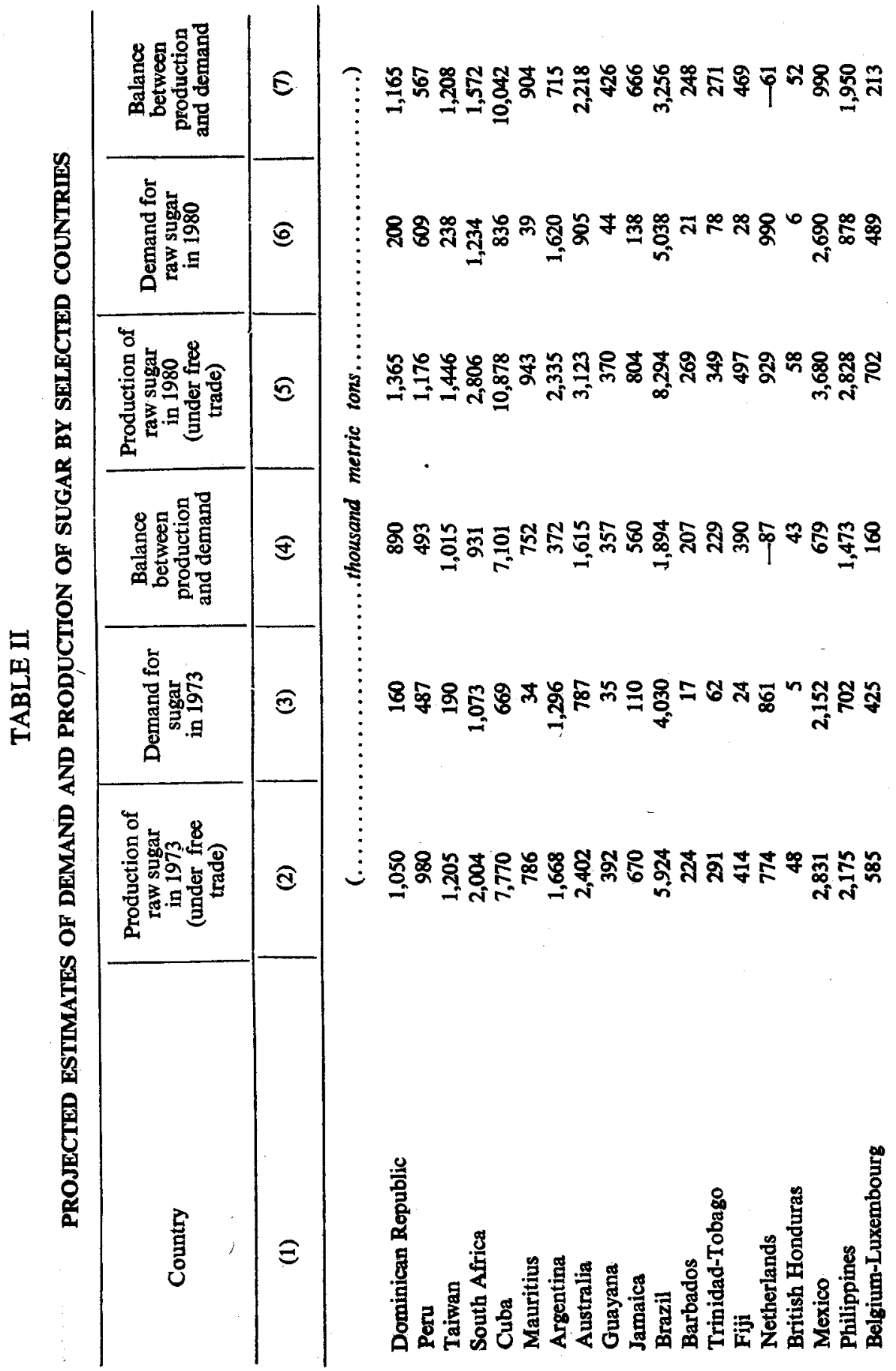




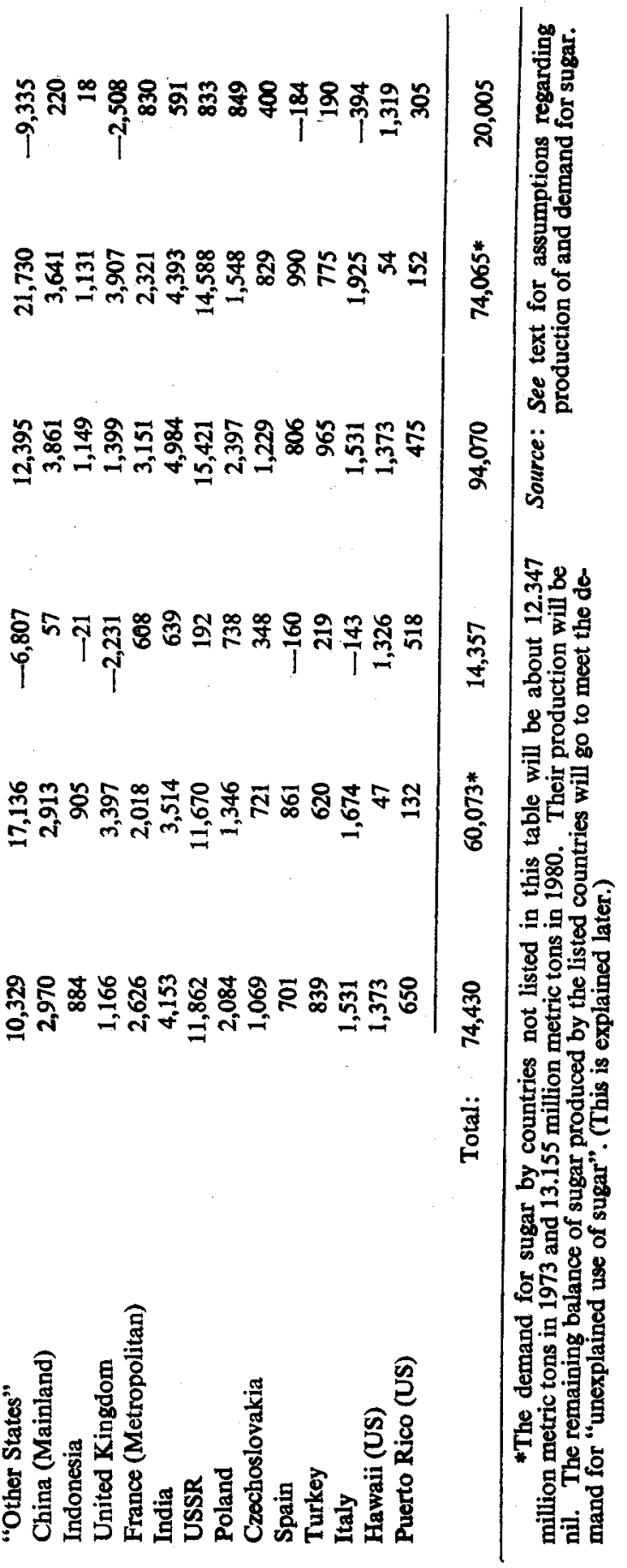


demand for sugar, the following rates of percentage increase in demand were projected:

Country or region

US and Europe, excluding USSR

USSR and Turkey

Oceania and Mauritius

China and India

"Other States"

Developing countries, excluding Latin America

Barbados and Cuba

All other Central and Latin American countries

\begin{tabular}{c}
\hline $\begin{array}{c}\text { Percentage increase in } \\
\text { demand in 1980 over } \\
\text { that of } 1973\end{array}$ \\
\hline 18 \\
20 \\
20 \\
25 \\
26 \\
35 \\
40 \\
45 \\
\hline
\end{tabular}

Projected estimate of world demand in 1980 is 87.22 million metric tons or an increase of 21 per cent over the demand in 1973. The following rates of percentage increase in demand were assumed for selected countries:

\begin{tabular}{lc}
\hline \multicolumn{1}{c}{ Country or region } & $\begin{array}{c}\text { Percentage increase in } \\
\text { demand in 1980 over } \\
\text { that of 1973 }\end{array}$ \\
U.S.A. & 7 \\
Germany (West) & 12 \\
Europe, excluding USSR & 15 \\
Oceania, South Africa and Mauritius & 15 \\
All other countries & 25 \\
"Other States" & 27 \\
\hline
\end{tabular}

The total world production in the base period 1964-66 was 61.53 million metric tons. Projected production in 1973 is 74.43 million metric tons. The increase in production in 1973 over that of 1964-66 will be about 21 per cent. On the basis of the analysis in Chapter II of [13] and the FAO projections [7, Pp. 181-194], it was assumed that the following countries will be able to increase their production at various rates to meet the need of a 21-per-cent overall increase in production by 1973.

Countries capable of increasing production at constant cost by 50 per cent over that of the 1964-66 level are:

1. Dominican Republic

2. Cuba

3. Brazil

4. South Africa

5. Argentina 
Countries capable of increasing production at constant cost by 35 per cent over that of the 1964-66 level are:

1. Australia

2. Philippines

3. Mexico

4. Mauritius

5. USSR

6. "Other States"

7. China (Mainland)

Countries capable of increasing production at constant cost by 25 per cent over that of the 1964-66 level are:

1. All other countries not listed above.

The total estimated projection of world production in 1980 is 94.07 million metric tons. This is an increase of about 26 per cent over that of 1973. The assumed percentage increases in the production of sugar by the selected countries from the level of 1973 production are shown below:

\begin{tabular}{llll}
\hline$\overline{\text { Increase by }}$ & $\overline{\text { Increase by }}$ & $\overline{\text { Increase by }}$ & $\overline{\text { Increase by }}$ \\
40 per cent & 30 per cent & 20 per cent & 15 per cent
\end{tabular}
1. South Africa
1. Dominican
1. All other countries
1. Poland
2. Cuba Republic excluding Hawaii, Puerto Rico and Italy
3. Argentina
2. Australia
4. Brazil
3. Mexico
2. Czechoslovakia
3. Spain
4. China (Mainland)
4. Turkey
5. Indonesia
6. USSR

It was assumed that there will be no increase in the production of Hawaii and Italy, and that the production of Puerto Rico will declines.

5The cost of production of sugar in Hawaii and Italy is the same as the new world price. Other countries with lower prices are capable of meeting the world demand without an increase in production in Hawaii and Italy. Increases in production in these two countries will disturb the balance of supply and demand and will affect the world price much to their disadvantage. The production of sugar has been persistently declining in Puerto Rico since 1962 (see [13, Table II]) and sugar experts indicate that this trend will continue. 
Fourth, the world stock of sugar under free trade is assumed to be reduced annually until it reaches 5 million metric tons in 19806. The projection of total production reflects this assumption in Tables II and III.

The total production of sugar by the listed countries in 1973 is shown to be 74.43 million metric tons. Their total demand is 60.07 million metric tons. Out of the balance of 14.36 million metric tons, which is assumed to be equal to the demand for rest of the countries, 9,790 million metric tons will be supplied to the US mainland to meet its demand and 2,557 million metric tons to meet the demand of West Germany. The balance of 2.120 million metric tons of sugar will be used for purposes other than human consumption 7 . Similarly, out of the total production of 94.07 million metric tons in 1980, 74.065 million metric tons will be used by the listed countries and the balance of 20.005 million metric tons will be supplied to US mainland (10.414 million metric tons), West Germany (2.741 million metric tons), and the remainder will be used for purposes other than human consumption 8 .

\section{Estimated Gains and Losses from Free Trade in Sugar}

Table III summarises the implications of free trade in sugar on various countries. Column (1) shows the difference between the new world price of sugar $^{9}$ and cost of sugar production in each country. The balance of productionand-demand estimates is multiplied by the price-and-cost differences to show the gains or losses from free trade10. Some of the countries will sustain loss as the import price of sugar will be higher than their costs of production. Logically, such countries should produce more sugar rather than import. But, as explained earlier, further increases in their production of sugar are not feasible because of limitations of their natural resources conducive to sugar production.

The total net gain to the exporters of sugar from free trade in 1973 will be 941.707 million dollars. For the sake of simplicity in analysis, it is assumed that the aggregate gains to US mainland and West Germany from cheaper sugar

6The logic behind this assumption has been explained in Chapter II of [13].

TThis is referred to as "unexplained use of sugar" in [13]. "Unexplained use of sugar" is defined there as the difference between supply-demand balance (i.e., production + carryover stocks from previous-year consumption) and the end-year carryover stocks. One possible explanation for the "unexplained use of sugar" is that sugar is used for making industrial alcohol and is not reported under world consumption of sugar. A part of the "unexplained use of sugar" is probably due to estimation errors in either production or consumption.

8 See footnote 7 above.

9The new world price of sugar is $\mathbf{1 5 4 . 3 2}$ dollars per metric ton. The new price will be higher because the currently quoted world price of sugar is the price of a small percentage of sugar traded internationally. For details, see [13, Chapter III].

10The author fully understands the desirability of including costs of transportation in the analysis of gains and losses from trade. Since this study does not aim at showing the actual flow of trade between countries, it is not possible to add transportation costs arbitrarily. Moreover, it is difficult to get data on transportation costs of sugar. Transportation costs are not high enough to be significant, anyway. 


\section{TABLE III}

ESTIMATED GAINS AND LOSSES FROM FREE TRADE IN SUGAR IN 1973 AND 1980

\begin{tabular}{|c|c|c|c|}
\hline \multirow[t]{2}{*}{ Country } & $\begin{array}{l}\text { Difference between } \\
\text { the new world price } \\
\text { and cost of production* }\end{array}$ & $\begin{array}{l}\text { Gains or losses } \\
\text { from exported or } \\
\text { imported sugar in } \\
1973\end{array}$ & $\begin{array}{c}\text { Gains or losses } \\
\text { from exported or } \\
\text { imported sugar in } \\
1980\end{array}$ \\
\hline & (1) & (2) & (3) \\
\hline & (US dollars per metric ton) & \multicolumn{2}{|c|}{ (.....thousand dollars....) } \\
\hline Dominican Republic & 93.69 & 83,384 & 109,149 \\
\hline Peru & 82.67 & 40,756 & 46,874 \\
\hline Taiwan & 82.67 & 83,910 & 99,865 \\
\hline South Africa & 71.65 & 88,416 & 112,634 \\
\hline Cuba & 66.14 & 469,660 & 664,178 \\
\hline Mauritius & 55.11 & 41,443 & 49,819 \\
\hline Argentina & 55.11 & 20,501 & 39,404 \\
\hline Australia & 55.11 & 89,003 & 122,234 \\
\hline Guayana & 55.11 & 19,674 & 23,477 \\
\hline Jamaica & 55.11 & 30,862 & 36,703 \\
\hline Brazil & 49.60 & 93,942 & 161,498 \\
\hline Barbados & 44.09 & 9,127 & 10,934 \\
\hline Trinidad-Tobago & 44.09 & 10,097 & 11,948 \\
\hline Fiji & 44.09 & 17,195 & 20,678 \\
\hline Netherlands & 44.09 & $-3,836$ & $-2,689$ \\
\hline British Honduras & 38.58 & 1,659 & 2,006 \\
\hline Mexico & 38.58 & 26,196 & 38,194 \\
\hline Philippines & 33.07 & 48,712 & 64,487 \\
\hline Belgium-Luxembourg & 33.07 & 5,291 & 7,044 \\
\hline "Other States" & 33.07 & $-225,107$ & $-308,708$ \\
\hline China (Mainland) & 30.86 & 1,759 & 6,789 \\
\hline Indonesia & 22.04 & -463 & 397 \\
\hline UK & 22.04 & $-49,171$ & $-55,276$ \\
\hline France (Metropolitan) & 22.04 & 13,400 & 18,293 \\
\hline India & 16.53 & 10,563 & 9,769 \\
\hline USSR & 11.02 & 2,116 & 9,180 \\
\hline Poland & 11.02 & 8,133 & 9,356 \\
\hline Czechoslovakia & 11.02 & 3,835 & 4,408 \\
\hline Spain & 11.02 & $-1,763$ & $-2,028$ \\
\hline Turkey & 11.02 & 2,413 & 2,094 \\
\hline Italy & 0 & 0 & 0 \\
\hline Hawaii (US) & 0 & $\mathbf{0}$ & $\mathbf{0}$ \\
\hline Puerto Rico (US) & 0 & 0 & 0 \\
\hline Total: & & 941,707 & $1,312,711$ \\
\hline
\end{tabular}

The new world price is $\mathbf{1 5 4 . 3 2}$ dollars per metric ton. For production costs, see Table I. 
imports (per ton gains over domestic cost of production will be 11.03 and 16.54 dollars, respectively, for the United States and West Germany) will be cancelled by the aggregate losses to their respective economies arising out of a complete withdrawal from sugar production. Given this assumption, it is possible to conclude that the total net gains from free trade in sugar will be 941.707 million dollars in 1973 and 1.313 billion dollars in 1980 . The total gains to the sugarexporting, developing countries will be 1.012 billion dollars in 1973 and 1.398 billion dollars in 1980 . In both the years, the aggregate gains to the sugar-exporting, developing countries will exceed the total net gains to the world as a whole because some developed as well as developing countries under the category of "Other States", and the Netherlands, the United Kingdom and Czechoslovakia (and Indonesia in 1973) will lose from free trade in sugar. Thęir total losses will be 280 million dollars in 1973 and 369 million dollars in 1980. The real beneficiaries of free trade in sugar will be the developing, sugar-exporting countries. Among the developed countries, the benefits will go to Australia, South Africa, BelgiumLuxembourg, France, the United Socialist Soviet Republic (USSR) and Poland. Their total gains will be 206 million dollars in 1973 and 279 million dollars in 1980.

From the analysis in this section, it is apparent that the world free-trade price will be considerably higher than what it is now under the restrictive trading systems prevelant all over the world. The rise in price of internationally traded raw sugar may not necessarily change much the retail price of refined sugar for direct consumption. Refined sugar is overpriced all over the world. The effect of the new world price might be to reduce the refiners' or retailers' margins. The consumers may not be affected adversely under the changed prices. However, it is difficult to estimate any change in world-wide consumer welfare under uncertain circumstances. The estimated overall gain from free trade should, therefore, be understood in the context of the assumptions made in this section.

\section{An Alternative Policy}

As an alternative to unrestricted production and free trade, the developed countries with high costs of production (i.e., the United States, Canada, and all European countries except the Netherlands, Belgium-Luxembourg, France, the United Kingdom and other European nations under "Other States") as well as all other higher-cost producers of sugar enunciate a policy to limit their production of sugar to the 1964-66 level. They could then agree to import all the future increases in their demand for sugar from the countries whose production costs are at or below 138 dollars per metric ton. For brevity, let these latter countries be called 'low-cost' producers. Suppose the new price for sugar is 138 dollars per metric ton. It is assumed that this price would encourage producers who have a cost of 138 dollars per metric ton to expand production to the 
level required to meet the expanding world demand. They would be encouraged to expand, also, because a price of 138 dollars presumably includes a reasonable level of profit.

The new policy implies that there will be no form of restrictions or preferences in the internationally traded sugar. Under this policy, the high-costproducing nations will have to continue to subsidise their producers to enable them to remain in the business of sugar production. The financing for subsidies may come from sales taxes on sugar. The consumers may not gain economically as the price of imported sugar will continue to remain high because of taxation. The farmers and processors do not lose or gain either as the subsidy will remain enough to cover their costs including normal profits. The 'low-cost' producers of sugar, however, will gain considerably under these assumptions.

\section{Sources of Supplies of Sugar Under the Alternative Policy}

In Table IV, the projected estimates of demand for and production of sugar by the 'low-cost' producers are shown. The demand for sugar in 1973 and 1980 is the same as that presented in the section on free trade. The production estimates are also the same for all countries except the "Other States", China, Indonesia, France, the United Kingdom and India. "Other States" include some sugar producers in Europe whose individual costs of production are higher than 138 dollars per metric ton. These countries will keep their production level at the 1964-66 level. As a result, the projected rate of increase in production of sugar has been assumed to be lower for "Other States" under the alternative policy than under that of free trade. The rates of increase in the production of sugar in Indonesia, France, the United Kingdom and India are also assumed to be lower because other cheaper producers can supply the bulk of the total world sugar requirements under the alternative policy. The high-cost countries are assumed to limit their production at the level of 1964-66. The average annual production of sugar by these countries during 1964-66 was 21.386 million metric tons. The 'low-cost' producers of sugar will have to produce 50.924 million metric tons in 1973 and 65.834 million metric tons in 1980 so as to meet their domestic demands for sugar and the increased demand for sugar for the high-cost producing countries. The total world production and demand for sugar will be the same under the alternative policy as under the free trade.

\section{Projected Gains to 'Low-Cost' Producers Under the Alternative Plan}

Table V summarises the estimates of projected gains to 'low-cost' sugarproducing countries. The total gains to these countries over their costs of production will be 756.988 million dollars and 1.299 billion dollars in 1973 and 1980, respectively. Out of these gains, the share of the developing countries 


\section{TABLE IV}

\section{ESTIMATES OF DEMAND AND PRODUCTION IN 'LOW-COST' SUGAR PRODUCING} COUNTRIES IN 1973 AND 1980a

\begin{tabular}{|c|c|c|c|c|c|}
\hline Country & $\begin{array}{c}\text { Actual } \\
\text { average } \\
\text { 1964-66 } \\
\text { production }\end{array}$ & $\begin{array}{l}\text { Estimated } \\
\text { demand } \\
\text { in } 1973\end{array}$ & $\begin{array}{l}\text { Estimatedb } \\
\text { production } \\
\text { in } 1973\end{array}$ & $\begin{array}{l}\text { Estimated } \\
\text { demand } \\
\text { in } 1980\end{array}$ & $\begin{array}{c}\text { Estimated } b \\
\text { production } \\
\text { in } 1980\end{array}$ \\
\hline \multicolumn{6}{|c|}{$(\ldots \ldots \ldots \ldots \ldots \ldots$ thousand metric tons............) } \\
\hline Dominican Republic & 700 & 160 & 1,050 & 200 & 1,365 \\
\hline Peru & 784 & 487 & 980 & 609 & 1,176 \\
\hline Taiwan & 964 & 190 & 1,205 & 238 & 1,446 \\
\hline South Africa & 1,336 & 1,073 & 2,004 & 1,234 & 2,806 \\
\hline Cuba & 5,180 & 669 & 7,770 & 836 & 10,878 \\
\hline Mauritius & 582 & 34 & 786 & 39 & 943 \\
\hline Argentina & 1,112 & 1,296 & 1,668 & 1,620 & 2,335 \\
\hline Australia & 2,174 & 787 & 2,402 & 905 & 3,123 \\
\hline Guayana & 290 & 35 & 392 & 44 & 470 \\
\hline Jamaica & 496 & 110 & 670 & 138 & 804 \\
\hline Brazil & 3,949 & 4,030 & 5,924 & 5,038 & 8,294 \\
\hline Barbados & 179 & 17 & 224 & 21 & 269 \\
\hline Trinidad-Tobago & 233 & 62 & 291 & 78 & 349 \\
\hline Fiji & 331 & 24 & 414 & 28 & 497 \\
\hline Netherlands & 619 & 861 & 774 & 990 & 929 \\
\hline British Honduras & 38 & 5 & 48 & 6 & 58 \\
\hline Mexico & 2,097 & 2,152 & 2,831 & 2,690 & 3,680 \\
\hline Philippines & 1,611 & 702 & 2,175 & 878 & 2,828 \\
\hline Belgium-Luxembourg & 468 & 425 & 585 & 489 & 702 \\
\hline "Other States" & 7,651 & 17,136 & 8,778 & 21,730 & 10,579 \\
\hline China (Mainland) & 2,200 & 2,913 & 2,043 & 3,641 & 3,641 \\
\hline Indonesia & 707 & 905 & 807 & 1,131 & 907 \\
\hline France (Metropolitan) & 2,188 & 2,018 & 2,246 & 2,321 & 2,321 \\
\hline United Kingdóm & 933 & 33,97 & 983 & 3,907 & 1,041 \\
\hline India & 3,322 & 3,514 & 3,514 & 4,393 & 4,393 \\
\hline Total: & 40,144 & 43,002 & 50,924 & 53,204 & 65,834 \\
\hline
\end{tabular}

'Low-cost' producers are countries having production costs at or below 138 dollars per metric ton.

bAs explained in the text, the high-cost countries' total production will remain constant at 21,386 million metric tons over the period 1967-80. For assumptions behind the estimates of demand and production for the individual countries, see the text.

(i.e., countries excluding South Africa, Australia, the Netherlands, BelgiumLuxembourg, France and the United Kingdom) will be 624.026 million dollars in 1973 and 1.062 billion dollars in 1980. The major beneficiary of the new policy will, therefore, be again the developing sugar-exporting countries. Under this policy, there would be no cost of readjustment of economies as no country would go out of sugar productions. The only sacrifice that the high-cost countries will have to make will be to keep their productions of sugar at the 


\section{TABLE V}

\section{ESTIMATES OF PROJECTED GAINS TO 'LOW-COST' SUGAR PRODUCING COUNTRIES RESULTING FROM AN ALTERNATIVE WORLD SUGAR PROGRAMME $a$}

\begin{tabular}{|c|c|c|c|c|c|}
\hline Country & $\begin{array}{c}\text { Differenceb } \\
\text { between new } \\
\text { price and cost } \\
\text { of production }\end{array}$ & $\begin{array}{l}\text { Balance of } \\
\text { production } \\
\text { and demand } \\
\text { in } 1973\end{array}$ & $\begin{array}{c}\text { Balance of } \\
\text { production } \\
\text { and demand } \\
\text { in } 1980\end{array}$ & $\begin{array}{c}\text { Gains or } \\
\text { losses } \\
\text { in } 1973\end{array}$ & $\begin{array}{c}\text { Gains or } \\
\text { losses } \\
\text { in } 1980\end{array}$ \\
\hline & $\begin{array}{l}\text { (US dollars per } \\
\text { metric ton) }\end{array}$ & \multicolumn{2}{|c|}{ (thousand metric tons) } & (million & dollars) \\
\hline Dominican Republic & 77.37 & 855 & 1,424 & 66.151 & 110.175 \\
\hline Peru & 66.35 & 493 & 616 & 32.711 & 40.872 \\
\hline Taiwan & 66.35 & 1,015 & 1,268 & 67.345 & 84.132 \\
\hline South Africa & 55.33 & 1,065 & 2,187 & 58.926 & 121.007 \\
\hline Cuba & 49.82 & 7,619 & 12,425 & 379.579 & 619.014 \\
\hline Mauritius & 38.79 & 781 & 980 & 30.295 & 38.014 \\
\hline Argentina & 38.79 & 483 & 1,226 & 18.736 & 47.557 \\
\hline Australia & 38.79 & 2,257 & 3,357 & 87.549 & 130.218 \\
\hline Guayana & 38.79 & 328 & 410 & 12.723 & 15.904 \\
\hline Jamaica & 38.79 & 510 & 637 & 19.783 & 24.709 \\
\hline Brazil & 33.28 & 2,288 & 5,071 & 76.145 & 168.763 \\
\hline Barbados & 27.77 & 207 & 259 & 5.748 & 7.192 \\
\hline Trinidad-Tobago & 27.77 & 229 & 286 & 6.359 & 7.942 \\
\hline Fiji & 27.77 & 390 & 490 & 10.830 & 13.067 \\
\hline Netherlands & 27.77 & -87 & -22 & -2.416 & -0.611 \\
\hline British Honduras & 22.26 & 43 & 54 & 0.957 & 1.202 \\
\hline Mexico & 22.26 & 784 & 1,420 & 17.452 & 31.609 \\
\hline Philippines & 16.75 & 1,623 & 2,377 & 27.185 & 39.815 \\
\hline Belgium-Luxembourg & 16.75 & 84 & 147 & 1.407 & 2.462 \\
\hline "Other States" & 16.75 & $-8,358$ & $-11,151$ & -139.997 & -186.779 \\
\hline China (Mainland) & 14.54 & -510 & 0 & -7.415 & $\mathbf{0}$ \\
\hline Indonesia & 5.72 & -98 & -224 & -0.561 & -1.281 \\
\hline France (Metropolitan) & 5.72 & 228 & 0 & 1.304 & $\mathbf{0}$ \\
\hline United Kingdom & 5.72 & $-2,414$ & $-2,866$ & -13.808 & -16.394 \\
\hline India & 0.21 & 0 & 0 & 0 & 0 \\
\hline Total: & & 9,815 & 20,371 & 756.988 & $1,299.129$ \\
\hline
\end{tabular}

$a^{6}$ Low-cost' producers are countries having production costs at or below 138 dollars per metric ton.

Source: Table IV.

$b$ New price of sugar per metric ton is 138 dollars. Costs of production were shown in Tables I and II.

$c$ Balance of production and demand is estimated from Table IV. 
1964-66 levels. In return, they will be supplied with cheaper sugar from the 'low-cost' producers. Though the overall gain would be higher, given a policy of free trade, the policy under discussion here could bring tremendous benefits to the developing countries at a negligible cost to the developed nations.

\section{IMPLICATIONS OF PAKISTAN'S SUGAR POLICIES}

Pakistan has made impressive progress in the production of sugar in recent years. The total production of raw sugar has increased from 157 thousand metric tons in 1960 to 525 thousand metric tons in 1966 (see, Table VI). This rise in the production was possible because of the government-support policies to the sugar producers. Fair prices were fixed for the growers, costs of production of even the inefficient manufacturing units were assured and special incentives were given to the millers to increase their production. Low yield in sugarcane combined with low sucrose content and inefficiency in sugar processing results in high costs of sugar production in Pakistan. Despite the price support to the growers, sugarcane is not a very profitable crop to the farmers both in East and West Pakistan. The cost of sugarcane cultivation per acre is the highest of all the major crops grown in East Pakistan [4, Pp. 8-9]. This is also true for West Pakistan [15, Pp. 1-10]. The net return per acre from sugarcane is not much higher than other crops and, as a result, return per rupee cost incurred is lower in sugarcane than other major crops. It should be pointed out here that sugarcane, being a perennial crop, takes at least one crop year to mature. Thus, the net income per acre from growing sugarcane should at least be equal to the amount of the total net income that can be received from various crops from that land in a crop year to make it worthwhile to grow sugarcane. Without the government intervention in terms of support prices, it would not have been possible to induce farmers to grow sugarcane in Pakistan. It is true that the cost of sugarcane can be reduced, especially in East Pakistan, if better seeds, fertilizer and other known improved practices are applied. Since no serious efforts are being made in this direction, it is quite likely that the costs of production will continue to remain high in the foreseeable future.

Data for the cost of production of beet sugar are not available for Pakistan. In general, cost of beet sugar is found to be higher than cost of cane sugar [2]. It is unlikely that the case of Pakistan will be different. Beet sugar is such a small percentage of total sugar production in Pakistan that an aggregate estimate, like total cost of production of sugar in Pakistan, on the basis of the cost of production of cane sugar should be reasonably correct.

It has been pointed out in some studies $[1 ;$ see also 10$]$ that sugarcane does not have a comparative advantage in production over some major crops in Pakistan. It is grown only because of the pursuance of the government through various policies. In one study [1], the loss to Pakistan from growing sugarcane 


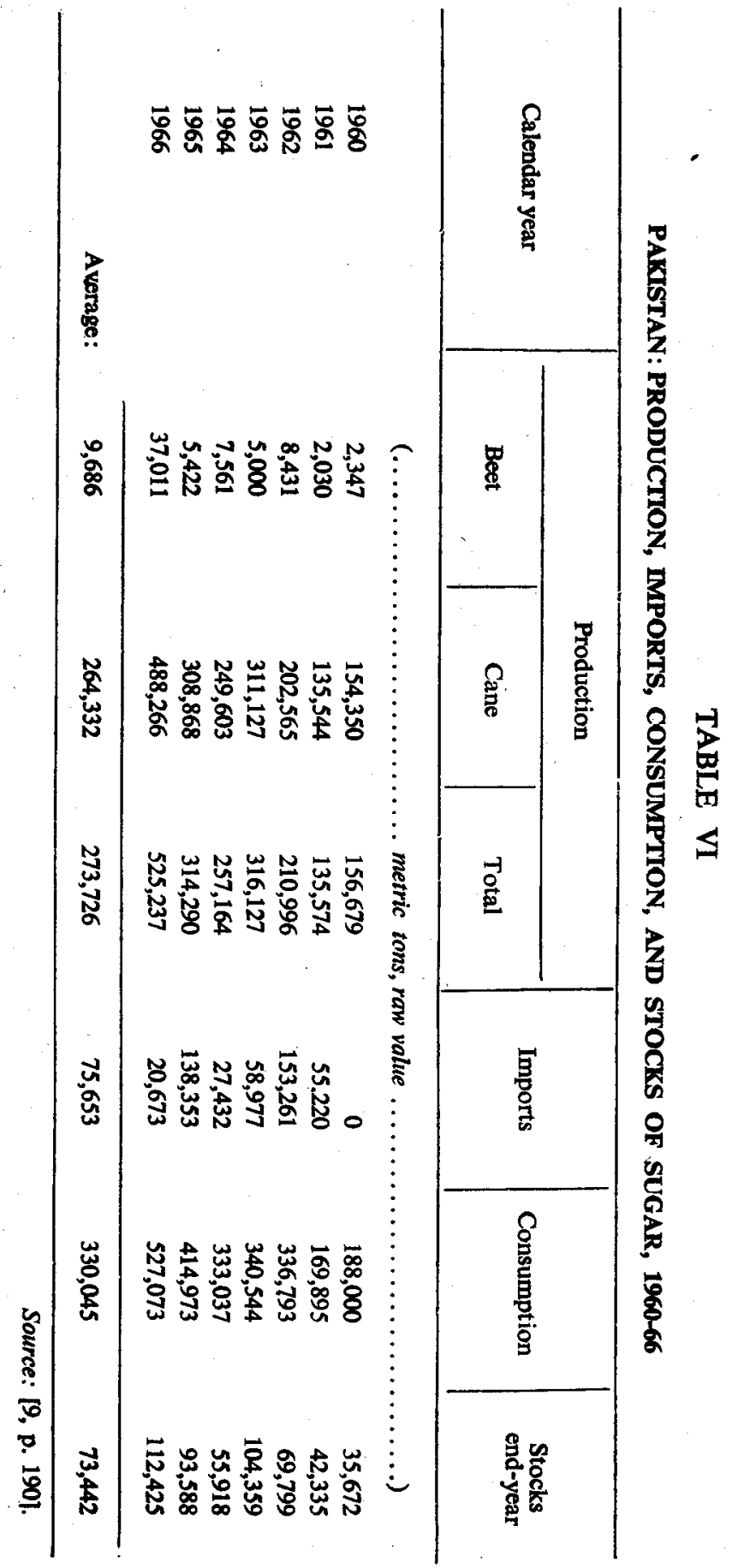


in West Pakistan was roughly estimated. It was shown that "the country on the average loses 155 rupees in foreign exchange for every 1.5 acres diverted from cotton to grow one acre of sugarcane"11 [1, p. 37]. The Sugar Enquiry Committee $[4, p .56]$ is of the opinion that the cost of production of sugar in Pakistan is about 25 per cent higher than the cost in India. The Pakistan Sugar Commission $[12$, p. 71] shows in a table that the comparative cost of production of sugar in India and Pakistan roughly confirms the observation made by the Sugar Enquiry Committee [4, p. 56]. The cost of production of sugar in Pakistan is estimated at 169 dollers per metric ton 12 . It may be recalled here that the costs of production of some of the efficient sugar producers are below 100 dollars per metric ton (see, Table I).

Under the present world trade systems in sugar, it appears to be quite profitable for Pakistan to import all its sugar requirements. The reason for this is that since the end of 1964 , the world price of raw sugar has been consistently below the cost of production of even the most efficient sugar producers in the world. During the 1960-66 period, the yearly average price of raw sugar was 76.06 dollars per metric ton. If Pakistan would have imported all its sugar requirements from the world market instead of producing a large portion of its requirements at home, it could annually save 25.466 million dollars (average annual domestic production during 1960-66 of 274 thousand metric tons multiplied by the domestic cost of production at 169 dollars per metric ton minus the value of this sugar at the world price of 76.06 dollars per metric ton) in terms of domestic resources.

Foreign exchange being very scarce but at the same time crucial for development of the overall economy, the agricultural policy of Pakistan has focussed on the attainment of self-sufficiency in foodgrains at any cost. These policies led to the wastage of domestic resources although it prevented drainage on foreign exchange. Pakistan has been supporting the prices of rice, wheat and sugar considerably above the world price levels. Under these support prices, production of these food crops increased considerably and there is further scope of expansion. In fact, what has been done in Pakistan is that import substitution has not only been encouraged in the industrial sector, but also in the foodgrain sector as well. Since most of the foodgrain imports were from the United States in the form of PL 480 wheat and rice, the agricultural policies of Pakistan have not been denying other less developed countries the prospect of exporting needed foodgrains to Pakistan and earning foreign exchange. This is not true

11Roughly, 155 rupees equal 31 dollars at the rate of Rs. $5=\$ 1$.

12The cost of production of sugar in India was shown as 137.79 dollars per metric ton in Table $\mathrm{I}$. If the cost of production is 25 per cent higher in Pakistan, then the actual cost should be 172.24 dollars per metric ton. However, the estimate for Pakistan [4, p. 54] shows it to be about 167 dollars. The cost figure used in this study is roughly the average of the two cost estimates. 
in the case of sugar because it is the developing countries who are the most efficient sugar producers and who have the comparative advantage in sugar production.

One may argue that the estimates of comparative costs in one monetary unit (here, US dollars) may be valid only if exchange rates are in equilibrium. This critical requirement is not fulfilled in most cases. Converting the rupee costs of production in Pakistan to the official exchange rate of the US dollar, one is likely to get erroneous results. Assuming the shadow price of the exchange rate to be about 7.50 rupees to a US dollar, one can possibly argue that if the Pakistani costs of production were upto 50 per cent higher than the world price for sugar, then we are not in a comparatively disadvantageous position in sugar production. Since Pakistan's cost of production is more than 200 per cent higher than the world price for sugar (world price 76.06 dollars per metric ton), it is clear that we should cease to produce sugar. The amount of foreign exchange earned from the crops replacing sugar will probably more than offset the foreign-exchange cost of importing sugar from the world market ( see [1], for some indications in this direction).

The analysis in Section II on the implications of world-wide free trade can be extended here for Pakistan. It is assumed that if the current sugar policies are continued, Pakistan would be able to meet its future demands for sugar from domestic production. The demand for sugar in Pakistan in 1973 and 1980 will be 616 and 770 thousand metric tons, respectively. The increase demand in 1973 over that of the average level of 1964-66 (425 thousand metric tons) is assumed to be 40 per cent and the increase in 1980 over that of 1973 to be 25 per cent (see, Section II).

As explained in Section II, the world price of sugar under a system of complete free trade was assumed to be $\mathbf{1 5 4 . 3 2}$ dollars per metric ton. If Pakistan imports its entire sugar requirements, then it will cost Pakistan 95.061 million dollars (616 thousand metric tons $\times \$ 154.32$ ) in 1973 and 118.826 million dollars (770 thousand metric tons $\times \$ 154.32$ ) in 1980 . If, instead, Pakistan supplies its entire requirements, then the costs of sugar in 1973 and 1980 will be 104.104 million dollars (616 thousand metric tons $\times \$ 169$ ) and 130 million dollars (770 thousand metric tons $\times \$ 169$ ), respectively. The savings from not producing domestically will be 9.043 million dollars in 1973 and 11.304 million dollars in 1980. It may be recalled that if sugar is not produced domestically, there will be no loss in farm income as there are other better alternative crops that can be grown on the land withdrawn from sugar production.

If the current world policies on sugar production and trade are continued and there is no free trade in sugar, it becomes more profitable for Pakistan to import sugar from the "world surplus market" than to produce domestically. In a situation of continued imperfection in the world trade, the world sugar 
price is likely to remain as low as the average price of 1960-67. In such a situation, by importing sugar, Pakistan will save 57.251 million dollars in 1973 ( $\$ 104.104$ - $\$ 46.853$ million, the figure of 46.853 dollars is derived by multiplying 616 thousand metric tons with 76.06 dollars) and 71.564 million dollars in 1980 (\$130.130 —58.566 million, in which the latter figure was derived as explained above).

If, however, the alternative form of free trade, suggested in Section II, becomes operative, Pakistan will limit its production to the average level of 1964-66, i.e., to 366 thousand metric tons. The rest of the requirements for sugar will be imported. Under this policy, the cost of the total sugar will be 96.354 million dollars (366 thousand metric tons $\times \$ 169+250$ thousand metric tons $\times$ $\$ 138$ ) in 1973 and 117.606 million dollars (366 thousand metric tons $\times \$ 169$ +404 thousand metric tons $\times \$ 138$ ) in 1980 . Under this alternative form of free trade, again, Pakistan gains substantially. The gain in 1973 and 1980 will be 7.750 million dollars (104.104 million - 96.354 million) and 12.524 million dollars, respectively. Under any of the altered situations in the world trade for sugar and even under the current world trade system, it will be advantageous for Pakistan to change its current sugar policies.

\section{CONCLUDING REMARKS}

The concept of comparative costs provides valuable guidelines as to the gainful pattern of trade. It is also possible to see from the policies adopted by the less developed countries (Pakistan being the case in point) how and why politics and need cause policies which deviate from the comparative cost principle. All such deviations are not, however, identical. It seems obvious that when the deviation is for the purpose of encouraging desperately needed food production in a less developed country, the question is quite different from a policy adopted by the United States or a developed EEC country, which is beneficial to an already fairly affluent agricultural sector with more alternative opportunities and at the same time working to the detriment of less developed countries' export earnings 13 .

13For a complete description of the sugar policies of the developed as well as developing countries, see [13, Chapters II and III]. 


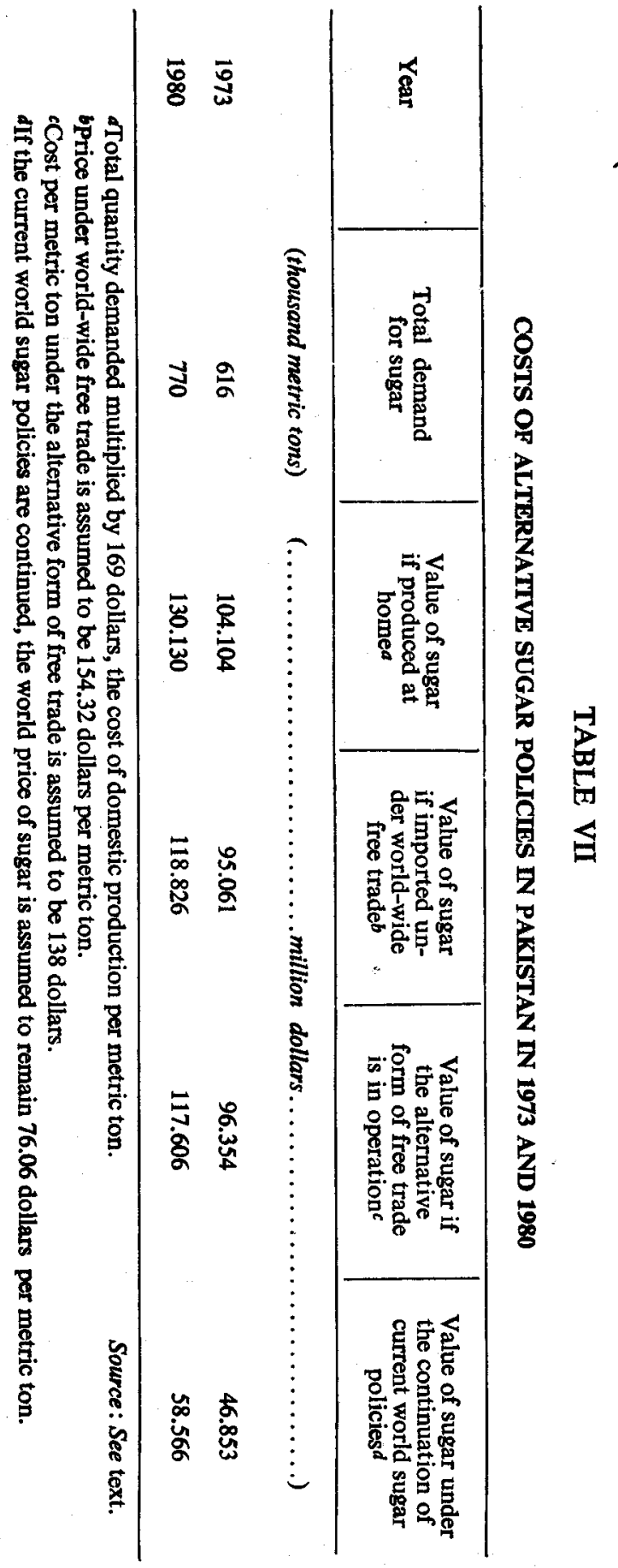




\section{REFERENCES}

1. Aslam, Ghayur, "Sugarcane: The Raw Material", Finance and Industry, September 1964, Vol. 3, No. 9.

2. Cambell, D. B., "Why Grow Sugar in Britain?", The South African Sugar Journal, December 1967.

3. Czarikow C. Ltd., Sugar, issue No. 409, 11 June.

4. East Pakistan, Department of Food, Report of the East Pakistan Sugar Enquiry Committee, 1961-62. (Dacca: Department of Food).

5. Fisher, Evan, "What is the Significance of the World Sugar Market?", Sugar Y Azucar, January 1967.

6. Food and Agriculture Organisation, Agricultural Commodities and the European Common Market. Commodity Policy Studies No. 13. (Rome: FAO).

7. Food and Agriculture Organisation, Agricultural Commodities-Projections for 1975 and 1985. (Rome: FAO).

8. International Sugar Council, Sugar Year Book, 1960 and 1967. (London: International Sugar Council).

9. International Sugar Council, Sugar Year Book, 1966. (London: International Sugar Council).

10. Johnson, Harry G., Economic Policies Towards Less Developed Countries. (New York: Frederick A. Praeger, 1967).

11. Kindleburger, Charles P., International Economics. 3rd edition. (Homewood, Illinois: Richard D. Irwin, Inc., 1963).

12. Pakistan, Ministry of Food and Agriculture, Report of the Pakistan Sugar Commission, 1957-59. (Karachi: Manager of Publications).

13. Raquibuzzaman, M., An Economic Appraisal of the Sugar Policies of Developed Countries and the Implications of these Policies to Developing Nations. An unpublished Ph.D. dissertation presented to the Faculty of the Graduate School of Cornell University in January 1970.

14. Snape, R. H., "Some Effects of Protection in the World of Sugar Industry", Economica, February 1963.

15. West Pakistan, Board of Economic Enquiry, Cost of Production of Major Crops, 1961-62 to 1963-64. (Lahore: Board of Economic Enquiry). 


\section{Appendix A}

Dr. Snape presented the following examples to illustrate the methods by which he estimated the average costs of production of raw sugar in 1959 for the selected countries shown in Section II [14, p. 73].

CUBA

\begin{tabular}{|c|c|c|}
\hline Market & $\begin{array}{l}\text { Quantity sold } \\
\text { ('O00' metric tons, } \\
\text { raw value) }\end{array}$ & $\begin{array}{l}\text { Average price received } \\
(U S \text { cents/pounds })\end{array}$ \\
\hline USA & 2,955 & 5.35 (f.a.s. Cuba) \\
\hline Other exports & 2,014 & 2.97 (f.a.s. Cuba) \\
\hline Cuba & 331 & $\begin{array}{l}3.75 \text { (Official wholesale price, } \\
\text { public warehouse, } \\
\text { Havana) }\end{array}$ \\
\hline All markets & 5,300 & 4.34 \\
\hline
\end{tabular}

Thus, the average price received by mills for sales was about 4.34 cents per pound less a 5 -per-cent tax on sugar produced 1 so that the net return, to the nearest $1 / 4$ cent per
pound 'was 4 cents per pound'.

\section{United States (Mainland)}

All domestically produced sugar is consumed within the United States. The c.i.f. price of imported sugar for the United States consumption in 1959 was 5.74 cents per pound, while the duty on sugar from the major foreign source (Cuba) was 0.5 cents per pound. Thus, the average price received by mainland mills and factories for raw sugar was about 6.24 cents per pound. Adding to this a direct subsidy which is paid to beet and cane which adds farmers and about 20 per cent to their total receipts, the average "cost" of raw sugar produced in the United States in 1959 would have been in the order of 7.5
cents per pound.

\section{Western Germany}

The retail price of sugar in 1959 was 13.4 cents per pound subtracting taxes (other than import duties) which form about 5 per cent of the retail price ${ }^{2}, 12.7$ cents per pound is obtained as the retail price net of taxes. Allowing 5 cents per pound for refining and distribution, the average cost of raw sugar produced would have been about 7.75 cents per pound. (Allowance for the small quantity of exports in 1959, for which a lower price was received, does not alter this figure.) 


\section{$\underline{\text { Appendix B }}$}

To estimate the cost of production of "Other States", first, the weighted average costs of production for Asia, Europe, Africa and Central and Latin American countries were determined. The weighted average price for each of the regions was based on the costs of production in the selected countries shown by Snape and included in Tables I and II. The weighted average costs were:

Asia

Europe

Africa

Central and Latin America
123.46 dollars per metric ton

143.30 dollars per metric ton 88.18 dollars per metric ton 95.02 dollars per metric ton

The second step was to select the countries (not included in Snape's study) whose production was higher than 100 thousand metric tons. The total production of sugar in 1967 of such countries in Europe was 3.976 million metric tons, in Central and Latin America 1.744 million metric tons, in Asia 1.554 million metric tons and in Africa 1.371 million metric tons. These production figures were used as weights to arrive at the weighted average cost of production of 121.25 dollars per metric ton for the "Other States". 